\title{
Countercyclical Taxes in a Monopolistically Competitive Environment*
}

\author{
Ioana R. Moldovan ${ }^{\dagger}$ \\ University of Glasgow
}

November 18, 2007

\begin{abstract}
In the context of a neoclassical growth model with monopolistic competition, this paper studies the stabilizing effects of countercyclical tax policy when the income tax rate has an additional role of financing government budget deficits. Consistent with the conventional wisdom, countercyclical taxes generally reduce aggregate volatility, unless the fiscal response to debt accumulation is weak. The presence of monopoly power enhances these effects. Even when automatic stabilizers successfully stabilize business cycle fluctuations, countercyclical taxes are welfare inferior, due to reduced precautionary saving motives. While, if the fiscal response to debt is weak and countercyclical tax policy destabilising, the increased precautionary saving motive is not welfare enhancing as the asset accumulated is government debt rather than capital.
\end{abstract}

- JEL Classification: E62, E32, H63

- Key Words: tax policy, countercyclical, stabilization, government debt, welfare

\section{Introduction}

The conventional wisdom states that countercyclical fiscal policies have stabilizing effects which help smooth out business cycle fluctuations. ${ }^{1}$ Supporting evidence comes primarily in the form of empirical estimates of various fiscal rules, with a focus on the

${ }^{*}$ This paper draws on my Ph.D. thesis written at Indiana University. I particularly wish to thank Eric Leeper for all his efforts in guiding me to create this paper. I thank Robert Becker, Campbell Leith, and Brian Peterson for useful discussions and suggestions. This paper also benefited from comments from Gregg Huff, Kim Huynh, Ioana Schiopu, Bill Witte and Susan Yang, and from seminar participants at the University of Edinburgh, the Midwest Macro Meetings 2007 FRB Cleveland, the SIRE Macro Conference 2007 Glasgow, and the Far Eastern Meetings of the Econometric Society 2007 Taipei. All errors are my own.

${ }^{\dagger}$ Department of Economics, University of Glasgow, Adam Smith Building, Glasgow, G12 8RT, U.K. Phone: +44(0)141330 8465. E-mail: i.moldovan@lbss.gla.ac.uk.

${ }^{1}$ See, for example, Auerbach and Feenberg (2000), Cohen and Follette (2000), Taylor (2000), Jones (2002), Auerbach (2003), Auerbach (2005), Kletzer (2005), Kim and Kim (2006). 
effects of such policies on output volatility. There is also a general consensus that countercyclical fiscal policy is most effective when it works via automatic stabilizers, which do not require active intervention from policy makers and therefore do not suffer from implementation lags. The focus of this paper is on the automatic stabilizer element of tax policy, as captured by a progressive tax system. In a recession, the reduced income implies lower income tax rates, which attenuate the negative effects of the economic downturn. Furthermore, the relative effects of this automatic stabilizer on key macroeconomic variables will vary with the degree of monopoly distortion present in the economy.

Countercyclical taxes also impact on the government budget deficit. During economic downturns, tax revenues are lower, due to both lower income and lower countercyclical tax rates. Debt-financing any such changes creates a dynamic link between current and future policies, as some future aspect of policy must adjust to balance the government budget in an intertemporal sense. This is important as expectations of future policies matter for the effectiveness of current policies. ${ }^{2}$ For example, higher expected future tax rates have adverse effects on current saving decisions. Focusing on this intertemporal margin, Gordon and Leeper (2005) show that countercyclical policies can be counterproductive, exacerbating and prolonging the business cycle.

This paper brings together these aspects of policy. It investigates the stabilization role and welfare consequences of countercyclical tax policy in an environment distorted by monopolistic competition in the product market, and where the government uses a single instrument, the income tax rate, to achieve its countercyclical objective and to satisfy the intertemporal government budget constraint. This dual role of fiscal policy is relevant, for example, in countries belonging to a monetary union where national governments have no control over monetary policy and must rely exclusively on fiscal policies to attain their goals. Also, governments generally have a wide range of objectives but a limited (and smaller) range of instruments, so a "one instrument - multiple objectives" policy is more likely to be the norm, rather than the exception. The government in the model economy adopts an endogenous simple rule where, in a manner which mimics the progressivity of the tax system, the income tax rate responds positively to contemporaneous output fluctuations and positively to lagged changes in government liabilities. The policy is evaluated for a range of empirically relevant parameters values.

Three main conclusions emerge. First, while it is generally true that countercyclical taxes reduce the volatility of some aggregate variables like output, investment, and consumption, others show an increase. In particular, employment variability is found to vary non-monotonically with the income elasticity of the tax rate, increasing under plausible parameter configurations. Also, market imperfections matter for the stabiliza-

\footnotetext{
${ }^{2}$ A selective list of articles which address this aspect includes: Bryant and Zhang (1996), Gordon and Leeper (2005), Leeper and Yang (2006), Yang (2007).
} 
tion effects of such policies. ${ }^{3}$ The monopolistic competition distortion tends to enhance the stabilization effects of countercyclical taxes, relative to the case of perfect competition. In the labor market, results depend on the degree of fiscal response to debt: a smaller response makes employment more volatile under monopolistic competition, while a stronger response reverses the results.

Second, considering the stabilization role of fiscal policy in isolation, there is a direct welfare benefit from the reduced volatility. However, when people take direct account of the level of uncertainty when making decisions, then the reduced volatility lowers the precautionary saving motive. Since the only asset available to households is physical capital, the lower level of precautionary savings will reduce capital accumulation and, therefore, consumption in the long run. This second effect dominates in welfare calculations.

Third, when requiring taxes to adjust to ensure fiscal solvency, the strength of the tax rate adjustment to fulfil this role crucially impinges on the stabilization role of automatic stabilizers. A slow fiscal response to debt allows more medium-run debt accumulation and makes changes in aggregate variables highly persistent. Furthermore, countercyclical taxes become destabilizing. However, allowing for a stronger response restores the stabilizing properties of countercyclical taxes. ${ }^{4}$

In contrast to the results without government debt, the precautionary savings effects of increased volatility are not necessarily welfare improving when there is a slow fiscal response to debt. This is because substitution between assets leads to the accumulation of the riskless government bond and decumulation of capital, so that the long-run level of consumption is still lower under countercyclical taxes.

Along some dimensions, the results of this paper are broadly consistent with the conventional wisdom, as countercyclical tax rates do tend to lower volatilities. At the same time, it is pointed out that some variables of interest, like employment, may become more volatile, especially in the presence of market distortions. The results also highlight that precautionary saving motives, the nature of the assets into which such savings are channelled, and the associated long-run effects on consumption, are crucial in determining the welfare implications of government policies. In the absence of precautionary savings, the stabilizing effects of countercyclical policy would unambiguously improve welfare, as Kletzer (2005) finds in an environment without capital. ${ }^{5}$ Finally,

\footnotetext{
${ }^{3}$ The role of frictions and distortions for the effects of tax policy are also discussed by Andres and Domenech (2006). They find that constant distortionary capital, labor, and consumption taxes help reduce output volatility (relative to lump-sum taxes), when ridigities due to price stickiness and investment adjustment costs are sufficiently large.

${ }^{4}$ The notion that a more aggressive fiscal adjustment to debt dynamics is beneficial is also present in Leeper and Yang (2006). However, in the context of a New Keynesian model with optimal monetary policy, it can be best to have a very small or mild fiscal feedback [Kollmann (2006), Schmitt-Grohe and Uribe (2006), and Kirsanova and Wren-Lewis (2007)]. These results are discussed in Section 4.1 below.

${ }^{5}$ The link between volatility and capital accumulation is present in Kim and Kim (2006) and Kollmann (2006) who, for certain specifications of their models, find that a countercyclical response of various
} 
the paper shows the importance of a careful consideration of debt dynamics.

The next section lays out the model, defines a symmetric equilibrium, and details the solution method and choice of parameter values. The direct effects of countercyclical taxes are presented in section three. Section four analyzes the interaction between the stabilizing role of taxes and their fiscal financing role. The last section concludes.

\section{A Model of Monopolistic Competition}

The economy consists of a perfectly competitive final goods sector, a monopolistically competitive intermediate goods sector, households, and the government. There is one composite good used for consumption and investment, and a continuum of differentiated goods used as inputs in the production of the final good.

\subsection{The Private Sector}

The Final Goods Sector Final goods are produced by an infinite number of firms in a perfectly competitive market. The available technology is of the Dixit-Stiglitz type

$$
Y_{t}=N_{t}^{\lambda}\left[\int_{0}^{N_{t}} m_{i t}^{\frac{\epsilon-1}{\epsilon}} d i\right]^{\frac{\epsilon}{\epsilon-1}}
$$

where $m_{i t}$ is the amount of each intermediate good $i, N_{t}$ is the measure of these goods, $\epsilon$ is the constant elasticity of substitution between them, and $\lambda$ governs the returns to scale. The markup, denoted by $\mu=\frac{\epsilon}{\epsilon-1}$, represents the degree of monopoly power of intermediate goods producers. Assuming constant returns to specialization, $\lambda$ is set equal to $1-\mu$.

Firms take as given the prices of intermediate goods and their measure and, subject to the available technology, choose the amount of each intermediate input $m_{i t}$ to maximize profits

$$
\max _{\left\{m_{i t}\right\}_{i}} \Pi_{t}=Y_{t}-\int_{0}^{N_{t}} P_{i t} m_{i t} d i .
$$

The first order condition yields the demand for intermediate goods

$$
m_{i t}=P_{i t}^{\frac{\mu}{1-\mu}}\left(\frac{Y_{t}}{N_{t}}\right), \quad \forall i
$$

The price elasticity of this demand is constant and depends negatively on the markup, $\mu$. The zero profit condition gives the following price index:

$$
1=N_{t}^{(\mu-1)}\left[\int_{0}^{N_{t}} P_{i t}^{\frac{1}{1-\mu}} d i\right]^{1-\mu} .
$$

distortionary taxes to exogenous technology shocks is optimal. 
The Intermediate Goods Sector The intermediate sector consists of a continuum of monopolistically competitive firms indexed by $i$ and of measure $N_{t}$. Each firm $i$ produces a unique good, using capital, $k_{t-1}$, and labor, $h_{i t}$, as inputs in the production process

$$
m_{i t}=z_{t} k_{i t-1}^{\alpha} h_{i t}^{1-\alpha}-\phi, \quad \alpha \in(0,1) .
$$

The production function exhibits increasing returns to scale due to the presence of positive fixed costs, $\phi$, but has a decreasing average cost and a marginal cost independent of scale. Total factor productivity, $z_{t}$, affects all firms symmetrically and follows an exogenous stationary process, $\ln z_{t}=\rho_{z} \ln z_{t-1}+\varepsilon_{t}^{z}$, with persistence parameter $\rho_{z} \in$ $(0,1)$ and random shocks $\varepsilon_{t}^{z} \sim \operatorname{iidN}\left(0, \sigma_{z}^{2}\right)$.

Monopolistic producers take as given the capital rental rate, $r_{t}$, and the real wage, $w_{t}$, as well as the amount of final goods, $Y_{t}$, and the measure of firms in the sector, $N_{t}$. Under these conditions and given the production technology (4) and the demand for their own good (2), firms choose factor inputs and the price level to maximize profits. Optimally, the price is set as a markup over marginal cost

$$
P_{i t}=\mu M C_{i t}=\mu\left(\Omega r_{t}^{\alpha} w_{t}^{1-\alpha} \frac{1}{z_{t}}\right)
$$

where $\Omega \equiv\left[\alpha^{-\alpha}(1-\alpha)^{\alpha-1}\right]$. The choices of capital and labor inputs are such that their marginal products exceed rental prices by the same constant markup $\mu$. (See Appendix A for more details.)

Focusing on a symmetric equilibrium, the firm specific capital, employment, and output can be expressed in terms of aggregate variables: $k_{i t-1}=k_{t-1}=\frac{K_{t-1}}{N_{t}}, h_{i t}=$ $h_{t}=\frac{H_{t}}{N_{t}}$, and $m_{t}=z_{t} K_{t-1}^{\alpha} H_{t}^{1-\alpha} / N_{t}-\phi$, where $K_{t-1}$ and $H_{t}$ are the aggregate levels of capital and employment. Prices are the same across firms and equal to unity, by the zero-profit condition of final goods producers. Aggregate final goods production can then be expressed as

$$
Y_{t}=N_{t} m_{t}=F_{t}-\phi N_{t}
$$

where $F_{t} \equiv z_{t} K_{t-1}^{\alpha} H_{t}^{1-\alpha}$ denotes aggregate output inclusive of fixed costs. Aggregate profits of intermediate producers, $N_{t} \pi_{t}=\left(1-\frac{1}{\mu}\right) F_{t}-\phi N_{t}$, are rebated to households in lump-sum fashion. Monopoly power has a positive effect on profits but fixed costs a negative one. Following Rotemberg and Woodford (1995), the measure of firms is fixed at the value needed to ensure profits in the deterministic steady state are zero. ${ }^{6}$

Households The representative household chooses consumption, $C_{t}$, capital, $K_{t}$, hours worked, $H_{t}$, and one-period risk-free government bonds, $B_{t}$, to maximize expected

\footnotetext{
${ }^{6}$ The other extreme is the assumption of free entry/exit in the intermediate goods sector. In that case, each firm in this sector produces a constant amount, $m_{i t}=\phi /(\mu-1)$, and all variation in aggregate output comes from changes in the measure of intermediate firms.
} 
lifetime utility

$$
E_{0} \sum_{t=0}^{\infty} \beta^{t}\left[\log C_{t}+\chi \log \left(1-H_{t}\right)\right]
$$

subject to the budget constraint

$$
C_{t}+K_{t}+B_{t} \leq\left(1-\tau_{t}\right)\left(r_{t} K_{t-1}+w_{t} H_{t}+N_{t} \pi_{t}\right)+(1-\delta) K_{t-1}+R_{t-1} B_{t-1} .
$$

$E_{t}$ is the mathematical expectation conditional on information available at time $t, \beta$ is the discount factor $(0<\beta<1)$, and $\chi$ is the relative weight on leisure in the utility. At the beginning of every period, households rent capital and labor to intermediate goods producing firms. At the end of each period, they receive capital rental payments, $r_{t} K_{t-1}$, wages, $w_{t} H_{t}$, and dividends, $N_{t} \pi_{t}$, all of which are being taxed by the government at a single income tax rate, $\tau_{t}$. Also included in household income are the value of undepreciated capital and payments on government debt. $\delta$ is the capital depreciation rate $(0 \leq \delta \leq 1)$ and $R_{t}$ is the gross real interest rate on one-period government bonds.

The first order condition for labor and the Euler equations for consumption and bonds, together with the two transversality conditions for capital and bonds, characterize the households' optimal choices. (See Appendix A for the detailed expressions.)

\subsection{The Government}

The government consumes an exogenous amount of final goods. They are financed by distortionary taxation and by issuing government debt. The period government budget constraint is

$$
G_{t}=\tau_{t} Y_{t}+B_{t}-R_{t-1} B_{t-1}
$$

where $G_{t}$ represents government consumption, $\tau_{t} Y_{t}$ distortionary tax revenues, $B_{t}$ the amount of newly issued government debt, and $R_{t-1} B_{t-1}$ the level of outstanding government liabilities. Government consumption follows a stationary $\mathrm{AR}(1)$ process, $\ln G_{t}=$ $\left(1-\rho_{G}\right) \ln \bar{G}+\rho_{G} \ln G_{t-1}+\varepsilon_{t}^{G}$, with persistence parameter $\rho_{G} \in(0,1)$ and random shocks $\varepsilon_{t}^{G} \sim \operatorname{iidN}\left(0, \sigma_{G}^{2}\right)$.

The income tax rate $\tau_{t}$ responds to contemporaneous output fluctuations and to lagged changes in the level of government indebtedness as follows

$$
\ln \tau_{t}=d+\theta \ln Y_{t}+\gamma \ln B_{t-1}, \quad \theta \geq 0, \quad \gamma>0,
$$

where $d$ is a constant term.

The dependence of the tax rate on output reflects the stabilization aspect of tax policy which occurs automatically, without intervention from policy makers. A positive $\theta$ indicates a countercyclical tax policy, an automatic response of the tax rate, which declines during recessions and increases during booms. In a broad way, this policy mimics the progressivity of the tax system. Fiscal financing is tax policy's other component. 
When the government issues debt to balance the budget, it must adjust future policies to service debt obligations and achieve intertemporal budget balance. The response of taxes to the level of government indebtedness must be such that the policy is sustainable. Only a certain range of values of $\gamma$ ensures that debt does not grow faster than the real interest rate, so that the transversality condition for debt holds. A minimal response of future taxes to current debt levels is required for equilibrium.

An implicit, and plausible, assumption is that government cannot implement subsidies to remove the distortion arising from imperfect competition.

\subsection{Equilibrium}

The dynamics of the economy are characterized by the first order conditions of households and firms, government policies, the government budget constraint, the aggregate resource constraint, and the exogenous processes. A symmetric equilibrium can be defined as:

Definition 1 A symmetric equilibrium is an allocation sequence $\left\{C_{t}, H_{t}, K_{t}\right\}_{t=0}^{\infty}$, a price sequence $\left\{P_{t}, w_{t}, r_{t}, R_{t}\right\}_{t=0}^{\infty}$, a sequence of government policy variables $\left\{G_{t}, \tau_{t}, B_{t}\right\}_{t=0}^{\infty}$, and initial conditions $\left\{K_{-1}, B_{-1}, z_{0}\right\}$ such that:

(i) given prices, government policies, and initial conditions, the allocation sequence solves the households' utility maximization problem and the final goods producers' profit maximization problem,

(ii) given factor prices, government policies, and initial conditions, the allocation sequence and the price sequence $\left\{P_{t}\right\}_{t=0}^{\infty}$ solve the profit maximization problem of intermediate goods producing firms,

(iii) fiscal policy variables follow the specified processes and the government budget constraint is satisfied at all times, and

(iv) all markets clear.

\subsection{The Solution}

In the absence of a closed form solution, the equilibrium conditions are approximated around the deterministic steady state. To compute welfare, a second-order accurate solution of the model was employed, using the algorithm in Schmitt-Grohe and Uribe (2004).

\subsection{Model Calibration}

The model is calibrated to a quarterly frequency and follows the usual parameterization in the literature. ${ }^{7}$ Table 1 gives some of the assumed and implied parameter values. The

\footnotetext{
${ }^{7}$ See, for example, Braun (1994), Jones (2002), Yang (2005), Leeper and Yang (2006), and Trabandt and Uhlig (2006).
} 
relative weight on leisure, $\chi$, is such that the proportion of time spent working averages $20 \%$. The capital depreciation rate $\delta$ matches the average investment-output ratio of 0.17 in the U.S. data (1947:1-2005:4). With a markup value $\mu$ of 1.4, the degree of monopolistic competition is moderate, in the context of a range 1.1 to 2.4 identified in the literature and, furthermore, consistent with values most commonly encountered in real models. Under monopolistic competition, the standard deviation of the technology shock is re-scaled, to allow for accurate comparisons across economies with different degrees of market power. ${ }^{8}$

The elasticity of the tax rate with respect to output, $\theta$, is allowed to vary in the $[0,2]$ range. This parameter represents the magnitude of the endogenous response of the income tax rate to output fluctuations, i.e. how countercyclical tax policy is. The specific range reflects available evidence: Blanchard and Perotti (2002) rely on institutional information to estimate the quarterly elasticity of tax revenues with respect to output and obtain an average over the post-war period of 2.08, with specific values ranging from 1.58 in 1947:Q1 to 1.63 in 1960:Q1 to 2.92 in 1997:Q4. This implies an average value of $\theta$, the elasticity of tax rates to output, of approximately 1 with plausible values of almost 2. Using the TAXSIM model of tax returns, Auerbach and Feenberg (2000) provide annual evidence on the change in the income tax rate for a one percent change in income. This implies an approximate value of $\theta$ between 0.32 and 0.92 . Cohen and Follette (2000) give similar estimates.

In the presence of government debt, the steady state debt-output ratio corresponds to an annual average ratio of privately held federal debt to GDP of 0.44 [1947-2005, Table 78, Economic Report of the President (2006)]. Consistent with this value and a government spending-output ratio of 0.2 is an income tax rate $\tau$ of $0.22 .{ }^{9}$ The parameter $\gamma$, measuring the response of future taxes to the level of government debt, is set so as to ensure the sustainability of the fiscal policy. For all values considered, a unique equilibrium exists. With only one period adjustment lag, plausible values of $\gamma$ must be on the lower side of the identified range. For illustration purposes, $\gamma=0.25$ is chosen as a "low" value and 0.75 as "high" value. ${ }^{10}$

\footnotetext{
${ }^{8}$ The presence of market power and increasing returns to scale leads to Solow residuals that tend to overestimate the true technology factor. See Hornstein (1993), Rotemberg and Woodford (1995), and Devereux, Head, and Lapham (1993) for detailed discussion.

${ }^{9}$ This value of the average marginal income tax rate lies in the range of estimates in the literature. Akhand and Liu (2002) give a rate of approximately 0.2, while Braun (1994) and Auerbach and Feenberg (2000) report a value of 0.25 .

${ }^{10}$ The simulations conducted below suggest that this parameter range is consistent with the differing speeds of fiscal adjustment found in the empirical work of Chung and Leeper (2007).
} 


\subsection{Monopolistic Competition}

Monopolistic competition differs from perfect competition because firms set prices above marginal costs and make profits on the margin. ${ }^{11}$ Any increase in output exceeds the corresponding increase in real labor costs. In comparison to perfect competition, this translates into larger percent changes in output for any given change in employment. The presence of monopoly power changes the relative weight of the income and substitution effects that arise from shocks to the economy: changes in employment tend to be lower, while variations in output, consumption, and investment are larger. In combination with the dynamics induced by the government's tax policy, this aspect will prove important for the stabilization properties of countercyclical taxes.

\section{The Stabilizing Role of Countercyclical Taxes}

To better assess the direct effect of countercyclical taxes, it is assumed, initially, that bonds are in zero net supply and that the government relies exclusively on lump-sum taxes to balance its budget every period and intertemporally. ${ }^{12}$ Lump-sum taxes replace government debt in the budget constraints of the government and households, and the tax policy rule becomes:

$$
\ln \tau_{t}=d+\theta \ln Y_{t}, \quad \theta \geq 0
$$

\subsection{An Accounting of Shocks}

Two types of shocks hit the economy and their characteristics are important in assessing the stabilization role of countercyclical taxes.

A Positive Government Spending Shock Exogenous and persistent increases in government spending reduce the present value of privately available after-tax income. This leads to an increase in the labor supply and higher equilibrium employment and output, but crowds out private consumption and investment. In the presence of market power, the negative effects of an increase in government spending are, however, more modest: a consequence of the fact that the change in output derived from an increase in employment exceeds the change in labor costs. Figure 1 presents the responses of consumption, hours worked, investment, and output under the two environments.

When taxes are countercyclical, the increased output leads to a contemporaneous increase in the income tax rate, which has adverse effects on all aggregate variables. The positive response of employment is reduced and so is the increase in output. Persistence of the shock creates expectations of higher future tax rates and lower expected aftertax rates of return on capital. Investment thus declines even further (relative to the

\footnotetext{
${ }^{11}$ See Blanchard and Kiyotaki (1987), Rotemberg and Woodford (1995), and Benassy (2002) for detailed expositions on monopolistic competition.

${ }^{12}$ In section 4, the fiscal financing role of taxation is considered alongside its stabilization role.
} 
case of acyclical tax rates) and capital accumulation is adversely affected. While in a perfectly competitive economy the change in taxes has virtually no contemporaneous effect on consumption, this effect is more substantial under monopolistic competition. The difference is mainly because, given the exogenous shock, monopolistic competition gives rise to a larger percent change in output and tax rates than perfect competition.

Overall, when faced with government spending shocks, countercyclical taxes help reduce the magnitude of changes in hours worked and output, but amplify the responses of investment and consumption.

A Positive Technology Shock A persistent increase in technology raises the demand for capital and labor. Higher wages make households substitute current work for future leisure. This substitution effect dominates the incentive to work less due to the higher income and leads to overall higher equilibrium employment, output, investment, and consumption.

These effects are, however, altered when tax rates become countercyclical which means that they increase when output is above its long run level (Figure 2). Such a policy reduces the positive income effect via higher tax payments; it also lowers after-tax real wages and capital rental rates. The substitution effect dominates and reduces the overall increase in employment or it can even cause hours worked to decline. As before, the persistence of the tax rate induces expectations of lower after-tax rates of return on capital and deters investment. Output, consumption, and investment increase less than if taxes were not countercyclical. Again, the effects on consumption are stronger in the presence of market power.

Employment and Technology Shocks The response of employment to changes in technology deserves further attention. In response to a positive technology shock, hours worked can decline when taxes are countercyclical. This can occur under both perfect and monopolistic competition. The main factors influencing the results are the degree of monopoly power, the progressivity of the tax system, and the persistence of the technology shock. All three contribute to a reduced employment response. Market power (larger value of the markup $\mu$ ) enhances the positive income effect, diminishing the supply of labor. The progressivity of the tax system affects the magnitude of changes in the tax rate and the after-tax wage rate, thus accentuating the substitution effect, which again reduces employment. Finally, the more persistent the shock, the lower the incentive of households to supply labor.

Conditional on the persistence of technology shocks and the amount of market power, one can find a value of the countercyclical parameter, $\bar{\theta}$, for which employment shows virtually no contemporaneous response to changes in productivity. Under the current calibration, $\bar{\theta}$ is approximately 1.81 under perfect competition and 0.74 under monopolistic competition - plausible values of $\theta$ according to the range identified in the literature. 
Figure 3 provides an illustration of the monopolistically competitive case. For values of $\theta$ greater than $\bar{\theta}$ employment decreases when a persistent positive technology shock occurs. More important, the higher is $\theta$, for $\theta>\bar{\theta}$, the larger the decline in hours worked, which represents a destabilizing effect of countercyclical taxes. For less persistent technological changes, the values of $\theta$ required to obtain such effects would be very large and would exceed the plausible range $[0,2]$.

\subsection{Stabilization Effects}

The conventional notion of stabilization policies is that they reduce the volatility of aggregate variables, and especially the volatility of output. But the focus on output volatility is not necessarily well grounded. As households are primarily concerned with the utility derived from the consumption of various quantities (including leisure), it is the volatility of consumption and hours worked that is relevant.

In the current model, countercyclical tax policies reduce output volatility measured as the standard deviation of fluctuations around the long-run average. The result is consistent with the literature. Countercyclical taxes are also found to decrease the volatility of investment and consumption. Figure 4 shows the percent changes in aggregate volatility induced by a countercyclical tax $(\theta>0)$ relative to a non-countercyclical $\operatorname{tax}(\theta=0)$. For $\theta$ equal to 1 for example, the volatility of these variables is reduced by about 20$25 \%$. Notice that, in the case of output, consumption, and investment, the relationship between volatility and the degree of progressivity of the tax system is almost linear. Also, countercyclical taxes have a stronger effect under monopolistic competition than under perfect competition, but differences are small.

With respect to employment however, results are a lot more sensitive to the values of the progressivity parameter $\theta$ and the markup $\mu$. Employment volatility under perfect competition is a non-monotonic function of $\theta$, decreasing for smaller responses of the tax rate to output fluctuations, and then increasing as these endogenous changes become larger. But, for all values of $\theta$ considered, a countercyclical tax rate always reduces the variability of hours worked. In contrast, in a monopolistically competitive world, the stabilizing effects of countercyclical taxes on employment are very small and limited to the lower range of $\theta$ values. In fact, fluctuations in hours worked increase for most values of $\theta$.

The dominant factors shaping the results are stabilization effects associated with changes in technology. One reason for the importance of these effects is that technology enters the production function multiplicatively: a one percent change in technology has a larger effect on output than a percent change in government spending. The other reason is the tax policy rule. Responses of the income tax rate to exogenous shocks are intermediated by the responses in output, which implies that actual changes of the tax rate to these shocks depend not just on the progressivity parameter $\theta$ but on the entire set of structural parameters. Among them, especially important is the persistence of the 
process $\left(\rho_{z}\right)$ and its relevance for employment volatility. Less persistent technological changes increase the incentive to work more, amplify employment fluctuations, and allow countercyclical taxes to have a stronger stabilizing effect. Figure 5 shows that, under perfect competition and relative to the benchmark value of $\rho_{z}=0.95$, countercyclical taxes reduce the volatility of employment when technology shocks are less persistent $\left(\rho_{z}=0.8\right)$, while the opposite occurs when technological changes are more persistent $\left(\rho_{z}=0.98\right)$. Similar results obtain under monopolistic competition, as shown in Figure 6.

\subsection{Welfare Implications}

This section analyzes the welfare implications of countercyclical income tax policies, in the absence of a fiscal financing role for tax policy. Although countercyclical taxes reduce the volatility of most economic variables, they may affect welfare negatively if agents take direct account of the level of uncertainty when making decisions.

Welfare is measured as the unconditional expectation of lifetime utility based on a second-order solution to the model. ${ }^{13}$ Use of a second-order solution is necessary because spurious welfare results may emerge from linear models that abstract from the effects of uncertainty on optimal decisions, see Kim and Kim (2003). Let the economy with no countercyclical taxes be the benchmark or reference economy and define welfare as:

$$
W^{r}=E \sum_{t=0}^{\infty} \beta^{t} U\left(C_{t}^{r}, H_{t}^{r}\right)
$$

Alternative policy regimes are associated with countercyclical tax policies with different levels of responsiveness of the tax rate to output fluctuations. They yield welfare $W^{a}$. Then, the welfare benefit, $\xi$, of countercyclical tax policy is expressed as the fraction of the consumption process under the non-countercyclical policy (or reference) regime that households must be given in order to be equally happy under the two types of tax policy:

$$
W^{a}=E \sum_{t=0}^{\infty} \beta^{t} U\left(C_{t}^{a}, H_{t}^{a}\right)=E \sum_{t=0}^{\infty} \beta^{t} U\left((1+\xi) C_{t}^{r}, H_{t}^{r}\right) .
$$

With logarithmic utility in both consumption and leisure, the expression for $\xi$ in percentage terms is

$$
\xi=\left[\exp \left((1-\beta)\left(W^{a}-W^{r}\right)\right)-1\right] \times 100 .
$$

A positive $\xi$ denotes that countercyclical taxes are welfare improving.

To obtain a measure of welfare, the momentary utility function is approximated by a second-order Taylor expansion with respect to its arguments. This yields an expression

\footnotetext{
${ }^{13}$ This analysis compares welfare in economies with different degrees of countercyclical taxes and it is not a "tax reform" type of exercise. Unconditional welfare is therefore the relevant welfare measure to use.
} 
in which period- $t$ utility depends on percent deviations and squared percent deviations of consumption and hours worked from the deterministic steady state. Note that when utility is logarithmic in consumption, the volatility of consumption does not directly affect welfare. (For the more general expression, see Appendix B):

$$
\begin{aligned}
W & =E \sum_{t=0}^{\infty} \beta^{t} U\left(C_{t}, H_{t}\right) \\
& =\frac{\bar{U}}{1-\beta}+E \sum_{t=0}^{\infty} \beta^{t}\left[\hat{C}_{t}-\chi \frac{H}{1-H} \hat{H}_{t}\right]+E \sum_{t=0}^{\infty} \beta^{t} \frac{1}{2}\left[-\chi \frac{H}{(1-H)^{2}}\right] \hat{H}_{t}^{2} .
\end{aligned}
$$

With a second order accurate solution to the model, optimal decisions depend both on the levels of state variables and on the amount of uncertainty in the economy. With greater uncertainty, risk-averse agents increase their savings and accumulate more assets. This affects the long-run average of economic variables although in the short run agents have to work more and consume less. It follows that the welfare measure includes two components: a first order component due to changes in the means of consumption and leisure, and a second order component due to the magnitude of fluctuations in these variables:

$$
\begin{gathered}
W^{\text {FirstOrder }}=\frac{\bar{U}}{1-\beta}+E \sum_{t=0}^{\infty} \beta^{t}\left[\hat{C}_{t}-\chi \frac{H}{1-H} \hat{H}_{t}\right] \\
W^{\text {SecondOrder }}=\frac{\bar{U}}{1-\beta}+E \sum_{t=0}^{\infty} \beta^{t} \frac{1}{2}\left[-\chi \frac{H}{(1-H)^{2}}\right] \hat{H}_{t}^{2} \cdot{ }^{14}
\end{gathered}
$$

The welfare benefits of each component $\left(\xi^{\text {FirstOrder }}, \xi^{\text {SecondOrder }}\right)$ can be determined by applying the formula in expression (8). ${ }^{15}$

Table 2 shows that welfare in a stochastic economy with countercyclical tax policies $(\theta>0)$ is lower than when tax rates do not change with output $(\theta=0)$. The second order components reflect the impact that countercyclical taxes have on employment volatility: $\xi^{\text {SecondOrder }}$ is positive under perfect competition, indicating reduced uncertainty and higher welfare, and negative under monopolistic competition, indicating increased volatility and lower welfare. The welfare benefits of reduced volatility are expectedly small and comparable with those obtained by Lucas (1987). Overall, uncertainty is

\footnotetext{
${ }^{14}$ Similar decompositions are used by Kollmann (2002), Bergin, Shin, and Tchakarov (2006), and Kim and $\operatorname{Kim}(2006)$.

${ }^{15}$ Numerically, the welfare measures are computed using the unconditional first and second moments of consumption and labor, which are obtained from the solution method (see Schmitt-Grohe and Uribe (2004) and the related Matlab programs). Alternatively, one can approximate welfare by the following average: $W=\frac{1}{S} \sum_{s=1}^{S} V_{s}$ where $V_{s}$ represents the discounted present value of utility, $V_{s}=\sum_{t=0}^{T} \beta^{t} U_{s t}$, and the utility function has been approximated by the second-order Taylor expansion. This approximation method gives similar results if the number of simulations is sufficiently large (e.g. $S=100,000$ ). Also, when the simulated paths begin at the deterministic steady state, it is important to discard a certain number of observations from each simulated time series to ensure that the stochastic economy is in the neighborhood of its true mean.
} 
lower in the economy with countercyclical taxes. Less uncertainty has the important effect of reducing capital accumulation and long-run consumption. These mean effects of reduced uncertainty outweigh the stabilization effects and make countercyclical taxes welfare reducing. For an income elasticity of the tax rate of 1.0, the overall welfare costs are $0.045 \%$ under perfect competition and $0.037 \%$ under monopolistic competition.

In an economy where uncertainty matters, the long-run level of the economy will differ according to the degree of uncertainty and the implied accumulation of capital. Accordingly, the average tax level will be different. Simulation results indicate that, the more countercyclical the tax rate, the higher is average marginal tax. While this is a feature of progressive tax systems, it represents a second source of lower long-run consumption under countercyclical taxes. In welfare calculations, it strengthens the mean effect.

These results highlight the importance of the precautionary saving incentives and the nature of the assets in which these savings are invested, in determining the welfare implications of various government policies. In their absence, the stabilization consequences of countercyclical policy improve welfare, see Kletzer (2005) for an example in an environment without capital. When the link between volatility and capital accumulation is present, then the relative size of the stabilization and mean effects determines the ultimate effect on welfare. Here, the mean effect dominates. In contrast, Kim and Kim (2006) find, in the closed-economy version of their model, a stronger stabilization component which makes countercyclical taxes welfare improving. In their model, labor, capital, or consumption taxes respond directly to technology shocks. This modeling aspect, while more abstract, implies no change in the average level of the tax rate, thus dampening the mean effect on welfare. ${ }^{16}$ In a New Keynesian model with optimal monetary and fiscal policy, Kollmann (2006) reports that the optimal response of the income tax rate to technology shocks is countercyclical only under flexible prices. ${ }^{17}$

\section{The Fiscal Financing Role of Taxes}

In reality, governments do not have access to lump-sum taxes but rather rely on debt to balance their budgets every period. Changes in government liabilities have implications for future policy: some aspects of policy must change to service interest payments and balance the budget intertemporally. The specific fiscal instrument that adjusts in the future matters for the effects of current policies. The assumption here is that future tax rates do so. The income tax rate therefore has both a stabilization (countercyclical)

\footnotetext{
${ }^{16}$ There are other dimensions along which the model in Kim and Kim (2006) is different from this paper's, among them: the assumed utility function, the types of exogenous shocks, the presence in their model of capital adjustment costs. The latter are likely to moderate the effects of uncertainty on capital accumulation and the associated long-run consumption.

${ }^{17}$ The fiscal rule also includes a direct response to government spending shocks, as well as a contemporaneous feedback on debt. The optimal tax rate response to government spending shocks is always negative.
} 
role and a fiscal financing role, and the government follows a tax policy rule like that in equation (6), reproduced here for convenience:

$$
\ln \tau_{t}=d+\theta \ln Y_{t}+\gamma \ln B_{t-1}, \quad \theta \geq 0, \quad \gamma>0 .
$$

This setup gains in realism and allows a careful treatment of government indebtedness and of the intertemporal government budget constraint.

The fiscal financing role of taxes gives rise to complex dynamics. To understand the mechanism at work, consider the case of no feedback from output to tax rates $(\theta=0)$, and assume that exogenous shocks are such that output has declined contemporaneously. As receipts from distortionary taxation fall, the government must issue new debt to satisfy its flow budget in the current period. Given the tax rule adopted, future taxes will rise in order to service the higher government liabilities. Expected higher future taxes reduce the expected rates of return on capital. This has the potential to lower the incentive to save and therefore amplify the negative effects on investment and worsen the downturn. But dynamics are intricate and the degree of intertemporal fiscal response to debt has important bearing on the results, as it affects the dynamic path of the tax rate and the accumulation of debt. A stronger reaction to debt (higher $\gamma$ ) causes a sharper rise in tax rates but also allows for a quicker return to long-run levels: as shocks wear out, tax revenues become sufficient for the government to retire debt more quickly. While with a slow response, more debt accumulates and the tax rate remains at aboveaverage levels for a long time. See Figure 7 for an illustration of impulse responses to a negative $1 \%$ technology shock under monopolistic competition. Investment decisions depend on the entire path of expected after-tax rates of return, which are negative in the short to medium run but become positive later on. The adverse effects of higher $\gamma$ on investment appear to be relatively modest.

Note that returning debt to its long-run level is a lengthy process. Even when the government takes more aggressive steps in reducing debt outstanding (i.e. higher $\gamma$ ), the process takes a long time, in the order of 50 years. Recent work by Chung and Leeper (2007) gives empirical support to such a specification.

With a (more) progressive/countercyclical tax (positive $\theta$ ), government relies more heavily on debt financing in recessions, since it suffers larger tax revenue losses due to lower income and lower tax rates. This causes a strong response of future taxes, even for small values of $\gamma$. Figure 8 shows the impulse responses to the same negative technology shock but for varying values of $\theta$. A "high $\theta /$ high $\gamma$ " combination can mean a sharper economic downturn but a relatively shorter-lived one, while a "high $\theta /$ low $\gamma$ " combination gives a milder but longer downturn. Countercyclical taxes initially diminish the change in aggregate variables but amplify it in the longer term. These effects appear particularly strong in the case of consumption.

The combined effects of the two roles of tax policy (captured by $\theta$ and $\gamma$ ) are reflected 
in the volatility of aggregate variables. Figure 9 shows the percent change in volatility due to countercyclical tax rates $(\theta>0)$ relative to the case of non-countercyclical taxes, for low and high levels of fiscal feedback. With a small reaction of future policies to debt (low $\gamma$ ), a more progressive tax system is destabilizing, as it increases the volatility of aggregate variables, particularly for consumption and hours worked. A more aggressive response to debt restores the stabilization role of countercyclical taxes. For example, when $\gamma=0.5$, countercyclical taxes reduce the volatility of consumption, investment, and output, and have the familiar non-linear effect on the variability of hours worked.

The monopolistic competition distortion continues to enhance the stabilizing effects of countercyclical taxes on output, investment, and especially consumption (in the case of increased volatility, market power dampens these negative effects). The difference to the case of perfect competition increases with the degree of fiscal response to debt. In addition, this imperfection in the product market has interesting consequences in the labor market: for hours worked, countercyclical taxes are more destabilizing under monopolistic competition than under perfect competition, if the response to debt dynamics

$(\gamma)$ is low. However, results are reversed if this response is high: countercyclical taxes become more stabilizing in the presence of market power.

\subsection{Welfare Consequences}

Simulation results indicate that private agents are worse off under countercyclical taxes, but this is not necessarily due to the reduced levels of precautionary savings found in the absence of debt. When the fiscal reaction to the level of government indebtedness is small $($ low $\gamma$ ), countercyclical taxes increase aggregate volatility. Because of this increase, countercyclical taxes give rise to a small welfare cost: under monopolistic competition, this welfare cost is $0.001 \%$ if $\theta=1.0$ and $0.059 \%$ if $\theta=2.0$. [See the top part of Table 3]. With more uncertainty in the economy, the precautionary saving motive is much stronger. However, with a "high $\theta /$ low $\gamma$ " parameter combination, private holdings of government bonds are on average higher and so is the average tax rate. People save more but also substitute away from capital and into the riskless asset, the government bond. Consequently, despite an increased precautionary saving motive, the economy experiences accumulation of government debt and decumulation of capital. Long-run output and consumption are therefore lower, which explains the large welfare losses associated with this policy. This illustrates the importance of identifying which type of asset households' accumulate their precautionary savings in, before concluding that such savings are welfare improving.

In contrast, under a strong adjustment of taxes to debt (high $\gamma$ ), countercyclical taxes reduce aggregate volatility, and so have a positive direct effect on welfare. This is illustrated for $\gamma=0.75$ in the bottom part of Table 3. As is the case without debt, the reduced uncertainty lowers the precautionary saving motive, reducing capital accumulation and causing a lower long-run level of consumption and lower overall welfare. 
In a normative sense, the results suggest that countercyclical taxes are better coupled with a more aggressive debt management policy. Such a policy contributes to less volatility in aggregate variables and improves welfare relative to alternative policies where corrections to the level of government debt are slow. This is in line with findings by Leeper and Yang (2006) who discuss the role of alternative financing options for the dynamic effects of permanent changes in capital and labor income taxes. However, in a flexible price economy not dissimilar to the one described here, Kollmann (2006) finds the optimal implied value of $\gamma$ is about -0.012 (negative but very small, even smaller than the "low" values considered here). ${ }^{18}$ In that environment, the monetary authority adopts a passive monetary policy rule, which effectively stabilizes the debt stock when the fiscal authority does not attempt to do so. In contrast, this paper is concerned with the trade-offs existent in a situation where only fiscal policy has the dual role described above and monetary policy, while not formally modeled, has a different objective.

\section{Conclusion}

This paper examined the implications of countercyclical taxes in a neoclassical growth model with monopolistic competition, distortionary taxation, and debt. The income tax rate has both a countercyclical, stabilization, role and a fiscal financing role of balancing the government budget in an intertemporal sense. The countercyclical aspect of tax policy is defined by the automatic response of the average marginal income tax rate to output fluctuations, capturing the progressivity of tax systems.

Consistent with the conventional wisdom, countercyclical taxes tend to reduce the variability of most, but not all, aggregate variables. Notably, employment volatility depends non-linearly on the degree of progressivity of the tax system and may increase especially in the presence of the market power distortion.

The welfare consequences of countercyclical tax rates are negative when the amount of uncertainty in the economy affects decisions directly. The reduced volatility lowers the precautionary saving motive and capital accumulation, thus leading to lower long-run consumption levels. These negative mean effects outweigh the stabilization gains.

Finally, the fiscal financing role of taxes can reverse their stabilization properties. Under a slow intertemporal adjustment to the level of government liabilities, countercyclical taxes are destabilizing and welfare reducing. Precautionary saving motives are higher due to increased uncertainty. However, substitution between assets leads to accumulation of the risk-free government bond and decumulation of capital, with the same

\footnotetext{
${ }^{18}$ Other papers which find it desirable to stabilize debt slowly include Schmitt-Grohe and Uribe (2006) and Kirsanova and Wren-Lewis (2007), both in the context of New Keynesian economies. However, the former paper specifies a rule in terms of tax revenues and ignores the progressivity of the tax system emphasized in the current paper, while the latter uses a linearised model, government spending as the fiscal policy instrument and abstracts from capital accumulation. As a result they will not trigger the precautionary savings effects stressed in this paper.
} 
negative effect on long-run consumption. A more aggressive debt management policy is therefore beneficial, as it restores the stabilization effects of countercyclical taxes and reduces their welfare costs.

\section{References}

Akhand, H., and H. Liu (2002): "Marginal income tax rates in the United States: a non-parametric approach," Journal of Monetary Economics, 49, 383-404.

Andres, J., And R. Domenech (2006): "Automatic Stabilizers, Fiscal Rules and Macroeconomic Stability," European Economic Review, 50(6), 1487-1506.

Auerbach, A. (2003): "Fiscal Policy, Past and Present," Brookings Papers on Economic Activity, 2003:1, 75-138.

(2005): "The Effectiveness of Fiscal Policy as Stabilization Policy," in The Effectiveness of Stabilization Policies, ed. by B. o. Korea, pp. 100-130.

Auerbach, A. J., and D. Feenberg (2000): "The Significance of Federal Taxes as Automatic Stabilizers," Journal of Economic Perspectives, 14(Summer), 37-56.

Benassy, J.-P. (2002): The Macroeconomics of Imperfect Competition and Nonclearing Markets: A Dynamic General Equilibrium Approach. The MIT Press, Cambridge, Massachusetts.

Bergin, P. R., H.-C. Shin, and I. Tchakarov (2006): "Does Exchange Rate Variability Matter for Welfare? A Quantitative Investigation of Stabilization Policies," European Economic Review, forthcoming.

Blanchard, O. J., and N. Kiyotaki (1987): "Monopolistic Competition and the Effects of Aggregate Demand," The American Economic Review, 77(September), 647666 .

Blanchard, O. J., and R. Perotti (2002): "An Empirical Characterization of the Dynamic Effects of Changes in Government Spending and Taxes on Output," Quarterly Journal of Economics, 117(4), 1329-1368.

Braun, A. R. (1994): "Tax disturbances and real economic activity in the postwar United States," Journal of Monetary Economics, 33, 441-462.

Bryant, R. C., And L. Zhang (1996): "Alternative Specifications of Intertemporal Fiscal Policy in a Small Theoretical Model," Manuscript.

Chung, H., and E. M. Leeper (2007): "What Has Financed Government Debt?" NBER Working Paper No. 13425. 
Cohen, D., and G. Follette (2000): "The Automatic Fiscal Stabilizers: Quietly Doing Their Thing," FRB New York Economic Policy Review, (April), 35-68.

Devereux, M. B., A. C. Head, and B. J. Lapham (1993): "Monopolistic Competition, Technology Shocks, and Aggregate Fluctuations," Economic Letters, 41, 57-61.

Gordon, D. B., And E. M. Leeper (2005): "Are Countercyclical Fiscal Policies Counterproductive," NBER Working Paper No. 11869.

Hornstein, A. (1993): "Monopolistic Competition, Increasing Returns to Scale, and the Importance of Productivity Shocks," Journal of Monetary Economics, 31, 299316.

Jones, J. B. (2002): "Has fiscal policy helped stabilize the postwar U.S. economy?," Journal of Monetary Economics, 49, 709-746.

Kim, J., AND S. H. Kim (2003): "Spurious Welfare Reversals in International Business Cycle Models," Journal of International Economics, 60, 471-500.

(2006): "Welfare Effects of Tax Policy in Open Economies: Stabilization and Cooperation," Manuscript, Tufts University.

Kirsanova, T., and S. Wren-Lewis (2007): "Optimal Fiscal Feedback on Debt in an Economy with Nominal Rigidities," Manuscript.

Kletzer, K. (2005): "Taxes and Stabilization in Contemporary Macroeconomic Models," Manuscript.

Kollmann, R. (2002): "Monetary policy rules in the open economy: effects on welfare and business cycles," Journal of Monetary Economics, 49, 989-1015.

(2006): "Welfare Maximizing Operational Monetary and Tax Policy Rules," Macroeconomic Dynamics, forthcoming.

Leeper, E. M., and S.-C. S. Yang (2006): "Dynamic Scoring: Alternative Financing Schemes," Journal of Public Economics, forthcoming.

Lucas, Robert E., J. (1987): Models of Business Cycles, Yrjo Jahnsson Lectures. Basil Blackwell Ltd, Cambridge, Massachusetts.

Rotemberg, J. J., And M. Woodford (1995): "Dynamic General Equilibrium Models with Imperfectly Competitive Product Markets," in Frontiers of Business Cycle Research, ed. by T. F. Cooley. Princeton University Press, Princeton, NJ.

Schmitt-Grohe, S., and M. Uribe (2004): "Solving Dynamic General Equilibrium Models Using a Second-Order Approximation to the Policy Function," Journal of Economic Dynamics and Control, 28, 755-775. 
(2006): "Optimal Simple and Implementable Monetary and Fiscal Rules: Expanded Version," NBER Working Paper No. 12402.

TAYlor, J. B. (2000): "Reassessing Discretionary Fiscal Policy," Journal of Economic Perspectives, 14(Summer), 21-36.

Trabandt, M., and H. Uhlig (2006): "How Far Are We From the Slippery Slope? The Laffer Curve Revisited," SFB 649 Discussion Paper 2006-023.

Woodford, M. (2002): "Inflation Stabilization and Welfare," Contributions to Macroeconomics, 2(1), 1-51.

- (2003): Interest and Prices: Foundations of a Theory of Monetary Policy. Princeton University Press, Princeton, NJ.

YAnG, S.-C. S. (2005): "Quantifying Tax Effects Under Policy Foresight," Journal of Monetary Economics, 58(2), 1557-1568.

(2007): "Do Capital Income Tax Cuts Trickle Down?," National Tax Journal, forthcoming. 


\section{A Analytical Details}

\section{A.1 The Intermediate Goods Sector}

The optimization problem of the monopolistically competitive firm is split into two parts: a constrained cost minimization problem and a constrained profit maximization problem.

The firm chooses capital and labor to minimize the cost of production subject to the available technology

$$
\begin{aligned}
C\left(r_{t}, w_{t}, m_{i t}, \phi\right) & =\min _{k_{i t-1}, h_{i t}}\left[r_{t} k_{i t-1}+w_{t} h_{i t}\right] \\
\text { s.t. } z_{t} k_{i t-1}^{\alpha} h_{i t}^{1-\alpha} & =m_{i t}+\phi
\end{aligned}
$$

Define $f_{i t} \equiv m_{i t}+\phi$ as the total output (inclusive of fixed costs) that each firm $i$ produces. The fixed costs $\phi$ are in terms of the produced good $i$. Use the constraint to solve for $h_{i t}, h_{i t}=\left(\frac{f_{i t}}{z_{t}} k_{i t-1}^{-\alpha}\right)^{\frac{1}{(1-\alpha)}}$, and then substitute for it in the cost minimization problem. The resulting demand functions for capital and labor are:

$$
k_{i t-1}=\left[\frac{\alpha w_{t}}{(1-\alpha) r_{t}}\right]^{1-\alpha}\left(\frac{f_{i t}}{z_{t}}\right)
$$

and

$$
h_{i t}=\left[\frac{\alpha w_{t}}{(1-\alpha) r_{t}}\right]^{-\alpha}\left(\frac{f_{i t}}{z_{t}}\right) .
$$

The total cost function is then:

$$
\begin{aligned}
T C_{i t} & \equiv C\left(r_{t}, w_{t}, m_{i t}, \phi\right)=r_{t} k_{i t-1}+w_{t} h_{i t} \\
& =\left[\alpha^{-\alpha}(1-\alpha)^{1-\alpha}\right] r_{t}^{\alpha} w_{t}^{1-\alpha}\left(\frac{f_{i t}}{z_{t}}\right)=\Omega r_{t}^{\alpha} w_{t}^{1-\alpha}\left(\frac{f_{i t}}{z_{t}}\right)
\end{aligned}
$$

where $\Omega \equiv\left[\alpha^{-\alpha}(1-\alpha)^{\alpha-1}\right]$. The marginal cost follows directly:

$$
M C_{i t}=\frac{\partial C\left(r_{t}, w_{t}, m_{i t}, \phi\right)}{\partial m_{i t}}=\Omega r_{t}^{\alpha} w_{t}^{1-\alpha} z_{t}^{-1}
$$

Then, given the minimum total cost of production and the demand for its own good (2), each firm $i, \forall i$, chooses the price of its good $P_{i t}$ to maximize profits:

$$
\begin{aligned}
\max _{P_{i t}} \pi_{i t} & =P_{i t} m_{i t}-C\left(r_{t}, w_{t}, m_{i t}, \phi\right) \\
\text { s.t. } P_{i t} & =\left(\frac{N_{t} m_{i t}}{Y_{t}}\right)^{\frac{1-\mu}{\mu}}
\end{aligned}
$$


$F O C\left(P_{i t}\right): \quad m_{i t}+P_{i t} \frac{\partial m_{i t}}{\partial P_{i t}}-\frac{\partial C\left(r_{t}^{k}, w_{t}, m_{i t}, \phi\right)}{\partial m_{i t}} \frac{\partial m_{i t}}{\partial P_{i t}}=0$

Re-arranging the first order condition obtains the characteristic relationship of a markup of the price over marginal cost:

$$
P_{i t}=\mu M C_{i t}
$$

The final step is to combine equations (10), (11), and (13) to derive the optimal choices of capital and labor given both the technology constraint and the demand constraint:

$$
P_{i t}\left[\alpha \frac{m_{i t}+\phi}{k_{i t-1}}\right]=\mu r_{t}
$$

and

$$
P_{i t}\left[(1-\alpha) \frac{m_{i t}+\phi}{h_{i t}}\right]=\mu w_{t}
$$

\section{A.2 The Households' Utility Maximization}

The solution to the utility maximization problem is obtained by solving the Lagrangian function:

$L=E_{0} \sum_{t=0}^{\infty} \beta^{t}\left\{U\left(C_{t}, 1-H_{t}\right)-\lambda_{t}\left[\begin{array}{c}C_{t}+K_{t}+B_{t}-\left(1-\tau_{t}\right)\left(r_{t} K_{t-1}+w_{t} H_{t}+\Pi_{t}\right) \\ -(1-\delta) K_{t-1}-R_{t-1} B_{t-1}+T_{t}\end{array}\right]\right\}$

FOCs:

$\left(C_{t}\right): \quad U_{1}\left(C_{t}, 1-H_{t}\right)=\lambda_{t}$

$\left(H_{t}\right): \quad U_{2}\left(C_{t}, 1-H_{t}\right)=U_{1}\left(C_{t}, 1-H_{t}\right)\left(1-\tau_{t}\right) w_{t}$

$\left(K_{t}\right): \quad U_{1}\left(C_{t}, 1-H_{t}\right)=\beta E_{t} U_{1}\left(C_{t+1}, 1-H_{t+1}\right)\left[\left(1-\tau_{t+1}\right) r_{t+1}+1-\delta\right]$

$\left(B_{t}\right): \quad U_{1}\left(C_{t}, 1-H_{t}\right)=\beta E_{t} U_{1}\left(C_{t+1}, 1-H_{t+1}\right) R_{t}$

$\operatorname{TVC}\left(K_{t}\right): \quad \lim _{T \rightarrow \infty} \beta^{T} E_{t} U_{1}\left(C_{t+T}, 1-H_{t+T}\right) K_{t+T}=0$

$\operatorname{TVC}\left(B_{t}\right): \quad \lim _{T \rightarrow \infty} \beta^{T} E_{t} U_{1}\left(C_{t+T}, 1-H_{t+T}\right) B_{t+T}=0$

With utility given by $U(C, 1-H)=\log (C)+\chi \log (1-H)$, the first derivatives are

$$
U_{1}(C, 1-H)=\frac{1}{C} \quad \text { and } \quad U_{2}(C, 1-H)=\chi \frac{1}{1-H}
$$




\section{B Approximation of the Utility Function}

To calculate the welfare associated with a given fiscal policy rule, the momentary utility is approximated by a second-order Taylor expansion. First, take a second-order Taylor expansion of $U\left(C_{t}, H_{t}\right)$ with respect to $\left(C_{t}, H_{t}\right)$ around the deterministic steady state values $\bar{C}, \bar{H}$ and express it in algebraic percent deviations:

$$
\begin{aligned}
U\left(C_{t}, H_{t}\right) \approx & \bar{U}+\left[U_{C}(\bar{C}, \bar{H}) \bar{C}\right] \frac{d C_{t}}{\bar{C}}+\left[U_{H}(\bar{C}, \bar{H}) \bar{H} \frac{d H_{t}}{\bar{H}}+\right. \\
+ & +\frac{1}{2}\left\{\begin{array}{c}
{\left[U_{C C}(\bar{C}, \bar{H}) \bar{C}^{2}\right]\left(\frac{d C_{t}}{\bar{C}}\right)^{2}+2\left[U_{C H}(\bar{C}, \bar{H}) \bar{C} \bar{H}\right]\left(\frac{d C_{t}}{\bar{C}}\right)\left(\frac{d h_{t}}{\bar{H}}\right)} \\
+\left[U_{H H}(\bar{C}, \bar{H}) \bar{H}^{2}\right]\left(\frac{d H_{t}}{\bar{H}}\right)^{2}
\end{array}\right\}
\end{aligned}
$$

Then, following Woodford (2002) and Woodford (2003), approximate the algebraic percent change by a second-order expansion in terms of logarithmic changes

$$
\frac{x_{t}-\bar{x}}{\bar{x}}=\frac{d x_{t}}{\bar{x}} \approx \hat{x}_{t}+\frac{1}{2} \hat{x}_{t}^{2} \quad \text { where }: \hat{x}_{t} \equiv \ln x_{t}-\ln \bar{x}
$$

Finally, substitute the logarithmic changes for the algebraic percent changes and keep only the terms of order $O(1)$ and lower to get

$$
\begin{aligned}
U\left(C_{t}, H_{t}\right) \approx \bar{U}+\left[U_{C}(\bar{C}, \bar{H}) \bar{C}\right] \hat{C}_{t}+\left[U_{H}(\bar{C}, \bar{H}) \bar{H}\right] \hat{H}_{t}+ \\
+\frac{1}{2}\left\{\begin{array}{c}
{\left[U_{C C}(\bar{C}, \bar{H}) \bar{C}^{2}+U_{C}(\bar{C}, \bar{H}) \bar{C}\right] \hat{C}_{t}^{2}+2\left[U_{C H}(\bar{C}, \bar{H}) \bar{C} \bar{H}\right]\left(\hat{C}_{t} \hat{H}_{t}\right)} \\
+\left[U_{H H}(\bar{C}, \bar{H}) \bar{H}^{2}+U_{H}(\bar{C}, \bar{H}) \bar{H}\right] \hat{H}_{t}^{2}
\end{array}\right\} .
\end{aligned}
$$

Given the functional form adopted here, the approximation reduces to:

$$
U\left(C_{t}, H_{t}\right) \approx \bar{U}+\hat{C}_{t}-\chi \frac{H}{1-H} \hat{H}_{t}-\frac{1}{2}\left[\chi \frac{H}{(1-H)^{2}}\right] \hat{H}_{t}^{2}
$$

which is equation (9) in the text. Note that, when the momentary utility is logarithmic in consumption, the variability of consumption does not directly affect lifetime utility (the last term in the last equation only includes the squared value of percent deviations in hours worked). 


\begin{tabular}{|c|l|c|l|}
\hline Parameter & Value & Parameter & Value \\
\hline \hline$\beta$ & 0.99 & $\tau$ & 0.22 \\
$\chi$ & 3.0 & $\rho_{G}$ & 0.925 \\
$\alpha$ & 0.36 & $\sigma_{G}$ & 0.014 \\
$\phi$ & 1.0 & $\rho_{z}$ & 0.95 \\
$\delta$ & 0.015 & $\sigma_{z}$ & $\{0.009(\mu=1.0)$ \\
& $0.006(\mu=1.4)$ \\
$B / Y$ & $0.44 \cdot 4$ & $\theta$ & {$[0,2]$} \\
$G / Y$ & 0.20 & $\mu$ & $\{1.0,1.4\}$ \\
\hline
\end{tabular}

Table 1: Parameter values used in simulations

\begin{tabular}{|l|c|c|c|}
\hline & Total $(\xi)$ & Mean Effect $\left(\xi^{\text {FirstOrder }}\right)$ & Second Order Effect $\left(\xi^{\text {SecondOrder }}\right)$ \\
\hline & \multicolumn{3}{|c|}{ Perfect Competition } \\
\hline$\theta=1.0$ vs. $\theta=0.0$ & -0.045 & -0.054 & 0.009 \\
$\theta=2.0$ vs. $\theta=0.0$ & -0.081 & -0.088 & 0.007 \\
$\theta=2.0$ vs. $\theta=1.0$ & -0.036 & -0.034 & -0.002 \\
\hline & \multicolumn{3}{|c|}{ Monopolistic Competition } \\
\hline$\theta=1.0$ vs. $\theta=0.0$ & -0.037 & -0.037 & 0 \\
$\theta=2.0$ vs. $\theta=0.0$ & -0.063 & -0.060 & -0.003 \\
$\theta=2.0$ vs. $\theta=1.0$ & -0.026 & -0.023 & -0.003 \\
\hline
\end{tabular}

Table 2: The welfare cost of countercyclical taxes in model without government debt (values are in percentage points)

\begin{tabular}{|l|c|c|c|}
\hline & Total $(\xi)$ & Mean Effect $\left(\xi^{\text {FirstOrder }}\right)$ & Second Order Effect $\left(\xi^{\text {SecondOrder }}\right)$ \\
\hline & \multicolumn{3}{|c|}{ Monopolistic Competition: $\gamma=0.25$} \\
\hline$\theta=1.0$ vs. $\theta=0.0$ & -1.362 & -1.361 & -0.001 \\
$\theta=2.0$ vs. $\theta=0.0$ & -11.138 & -11.086 & -0.059 \\
$\theta=2.0$ vs. $\theta=1.0$ & -9.911 & -9.858 & -0.058 \\
\hline & \multicolumn{3}{|c|}{ Monopolistic Competition: $\gamma=0.75$} \\
\hline$\theta=1.0$ vs. $\theta=0.0$ & -0.058 & -0.061 & 0.003 \\
$\theta=2.0$ vs. $\theta=0.0$ & -0.146 & -0.148 & 0.002 \\
$\theta=2.0$ vs. $\theta=1.0$ & -0.088 & -0.087 & -0.001 \\
\hline
\end{tabular}

Table 3: The welfare cost of countercyclical taxes under both slow adjustment (gamma = 0.25 ) and rapid adjustment (gamma $=0.75$ ) to debt dynamics, the case of monopolistic competition (values are in percentage points) 

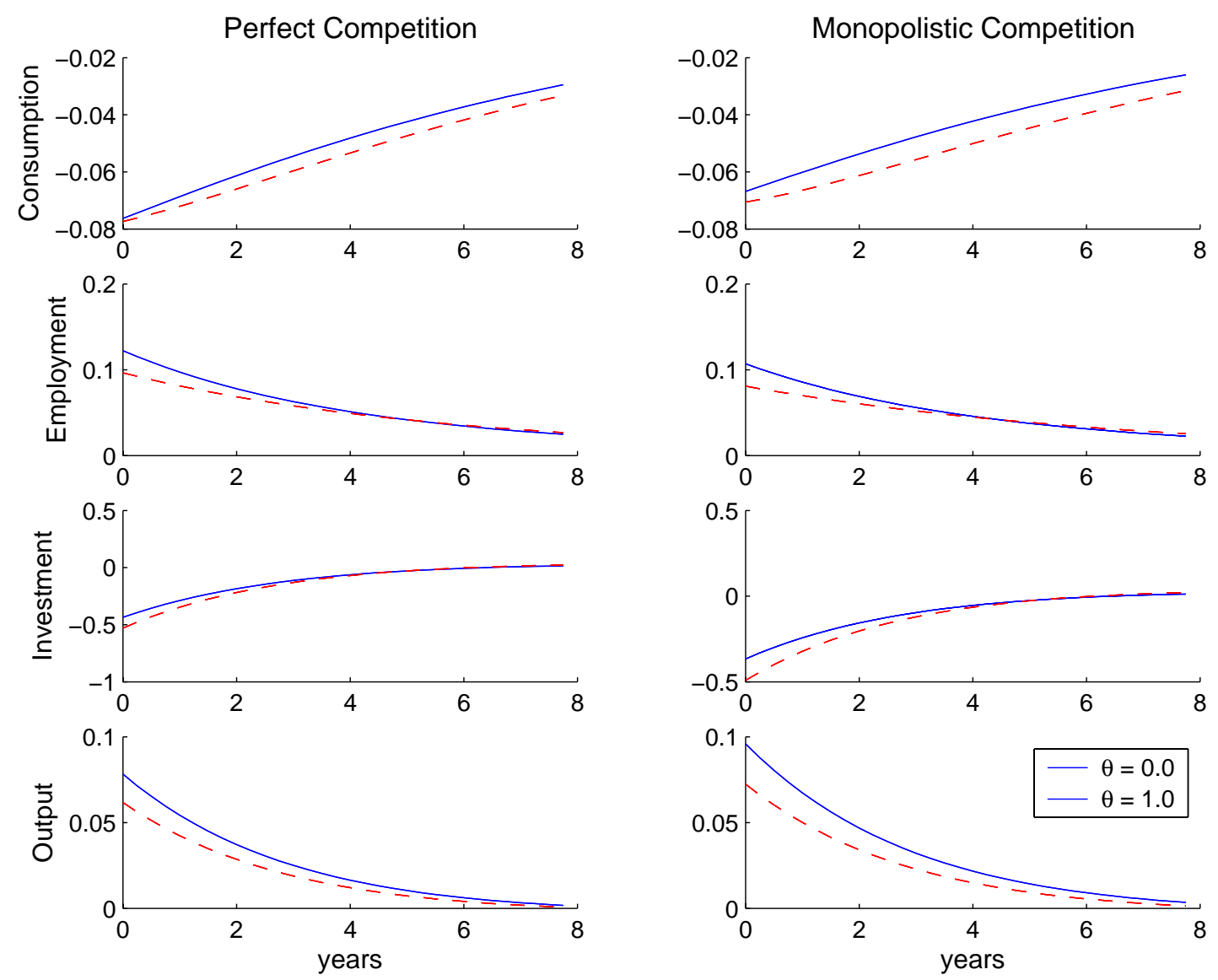

Figure 1: Impulse responses to a $1 \%$ increase in government spending under perfect competition (left column) and monopolistic competition (right column): acyclical tax rates $(\theta=0$, solid lines) and countercyclical tax rates $(\theta=1.0$, dash lines). 

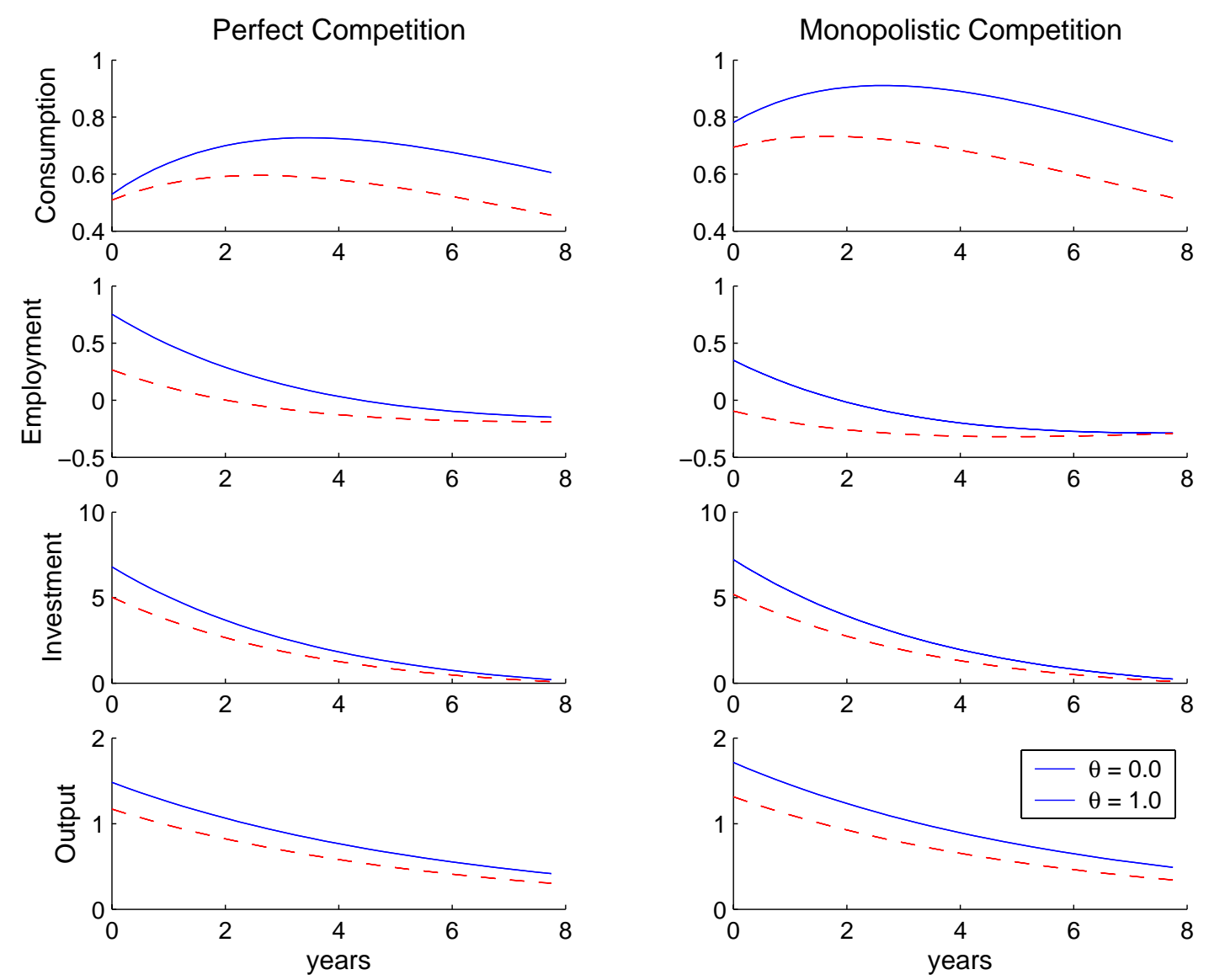

Figure 2: Impulse responses to a $1 \%$ increase in the technological factor under perfect competition (left column) and monopolistic competition (right column): acyclical tax rates $(\theta=0$, solid lines) and countercyclical tax rates $(\theta=1.0$, dash lines). 


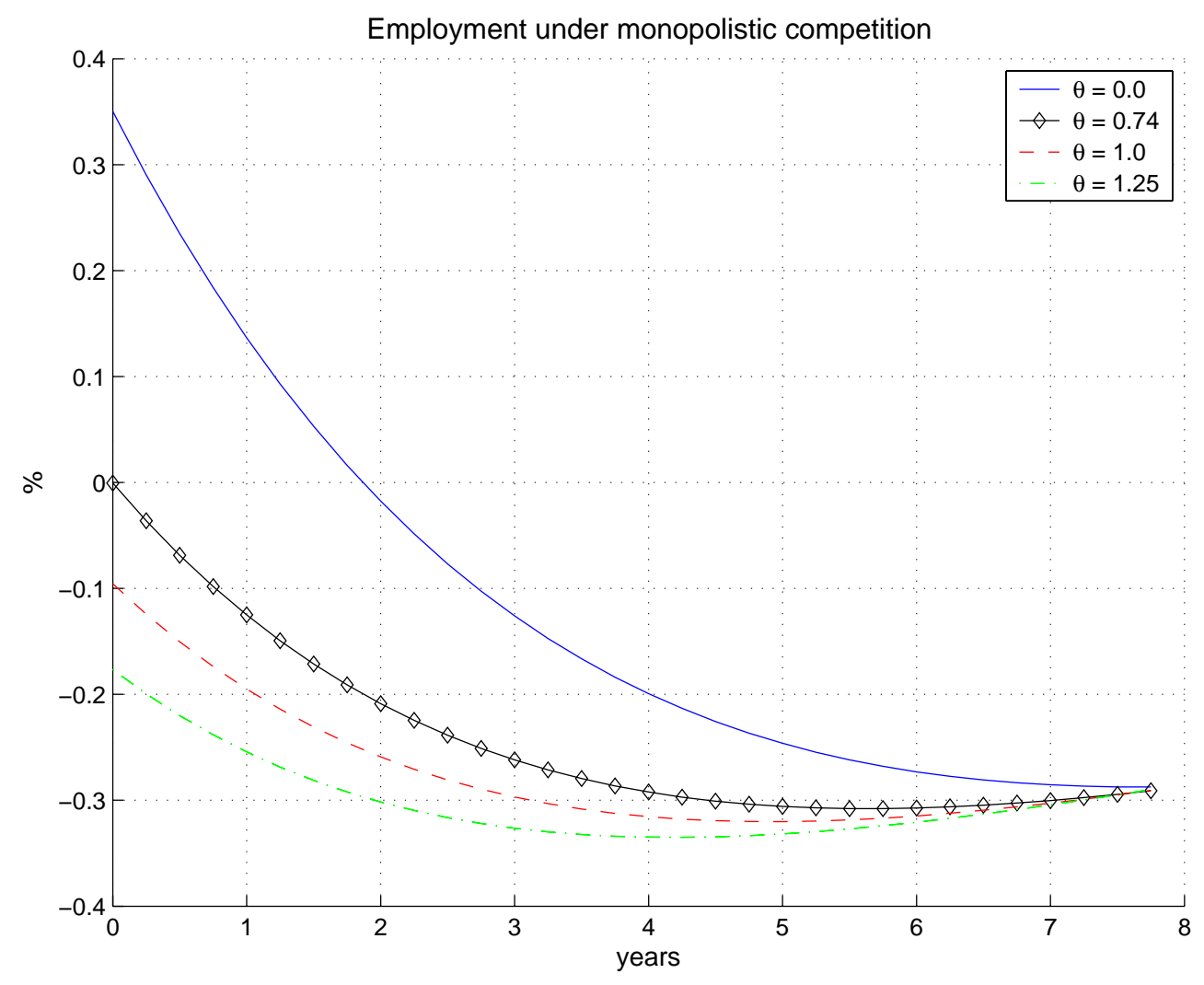

Figure 3: Impulse responses of hours worked to a $1 \%$ increase in the technological factor under monopolistic competition $(\mu=1.4)$ for $\theta$ equals to 0.0 (solid line), 0.74 (diamonds), 1.0 (dash line), and 1.25 (dash-dot line).
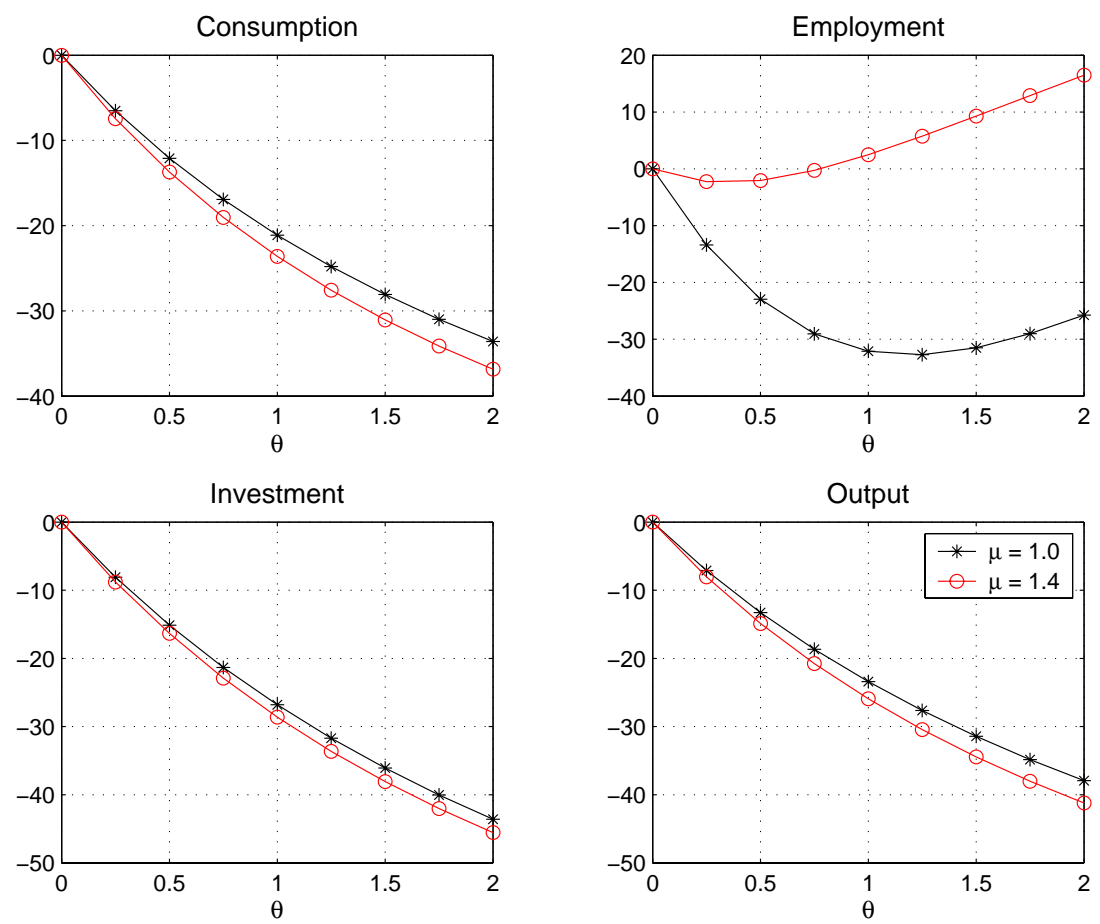

Figure 4: Percent changes in aggregate volatility as the tax rate becomes more countercyclical $(\theta>0)$ relative to acyclical taxes $(\theta=0)$ : perfect competition (stars) and monopolistic competition (circle). Volatility is measured as the standard deviation of fluctuations around the long-run average. 

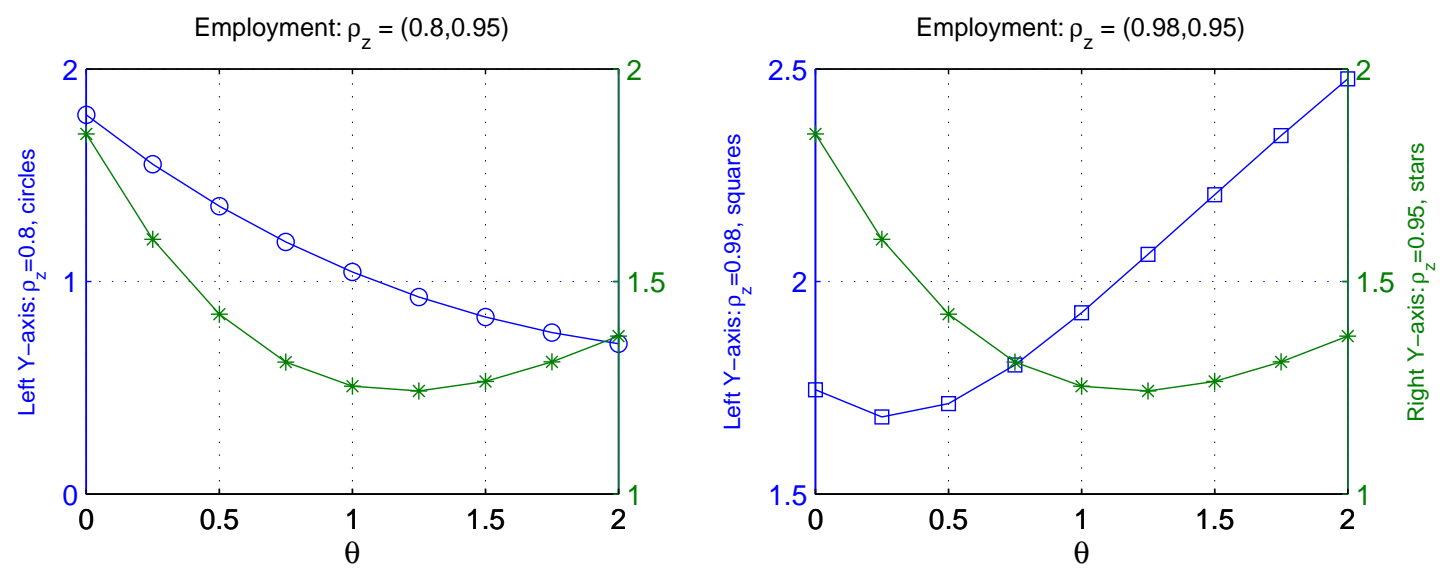

Figure 5: Employment volatility under perfect competition when technology shocks are less persistent, $\rho_{z}=0.8$ (circles, left panel, left axis), and more persistent, $\rho_{z}=0.98$ (squares, right panel, left axis), relative to the benchmark value of $\rho_{z}=0.95$ (stars, both panels, right axis).
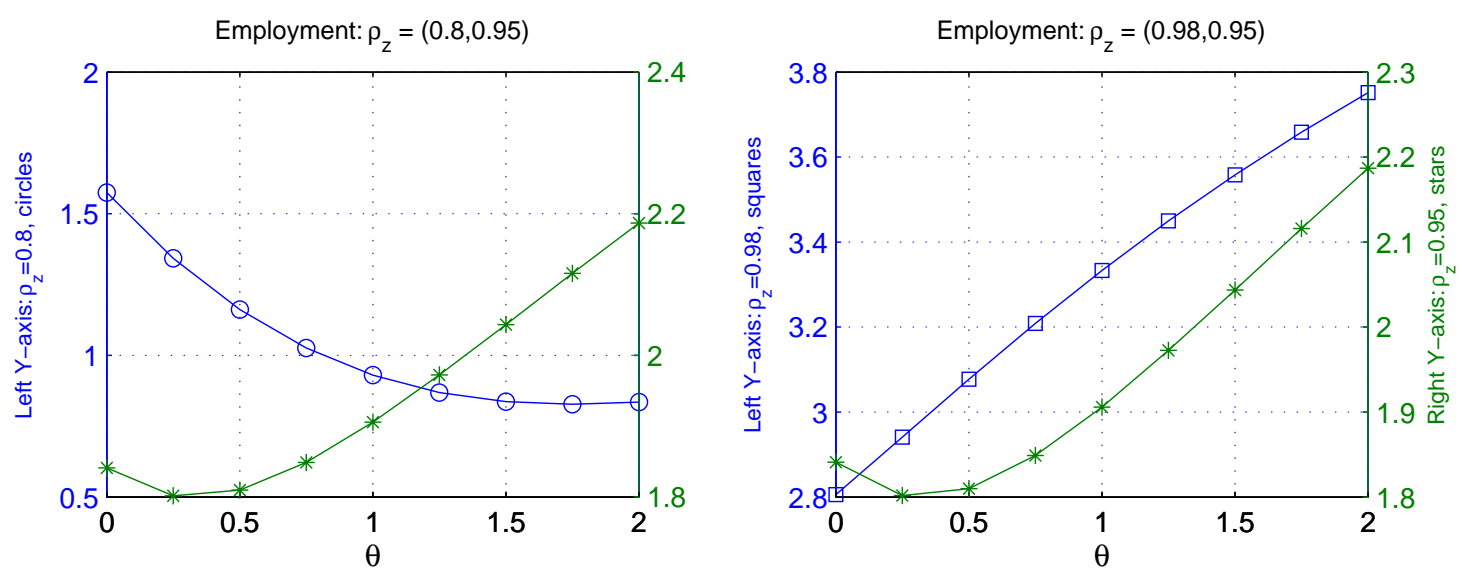

Figure 6: Employment volatility under monopolistic competition when technology shocks are less persistent, $\rho_{z}=0.8$ (circles, left panel, left axis), and more persistent, $\rho_{z}=0.98$ (squares, right panel, left axis), relative to the benchmark value of $\rho_{z}=0.95$ (stars, both panels, right axis). 

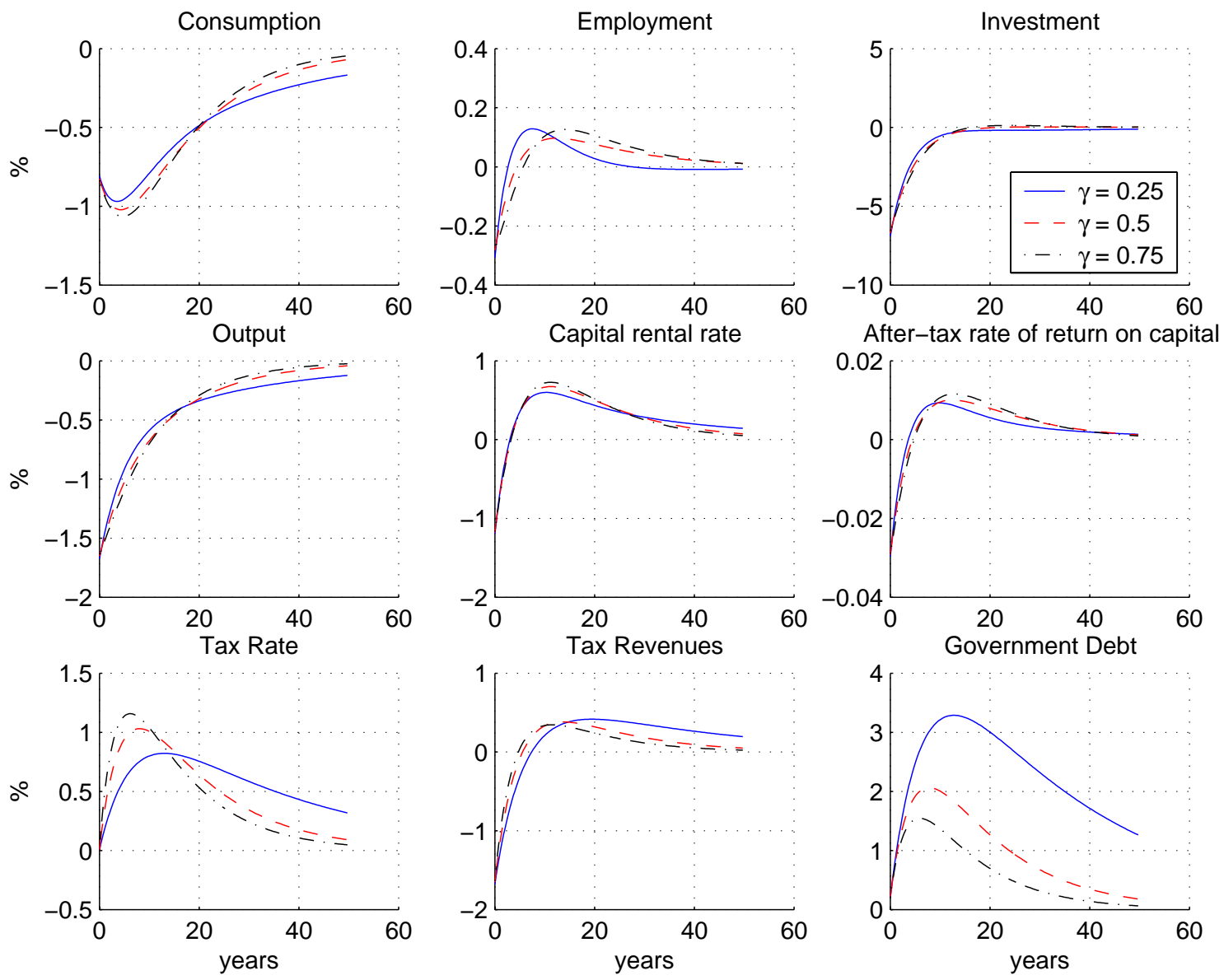

Figure 7: Impulse responses to a $1 \%$ negative technology shock under monopolistic competition and no automatic stabilizer element of taxes $(\theta=0)$, for varying degrees of the fiscal response to debt: $\gamma=0.25$ (solid lines), $\gamma=0.5$ (dash lines), and $\gamma=0.75$ (dash-dot lines). 

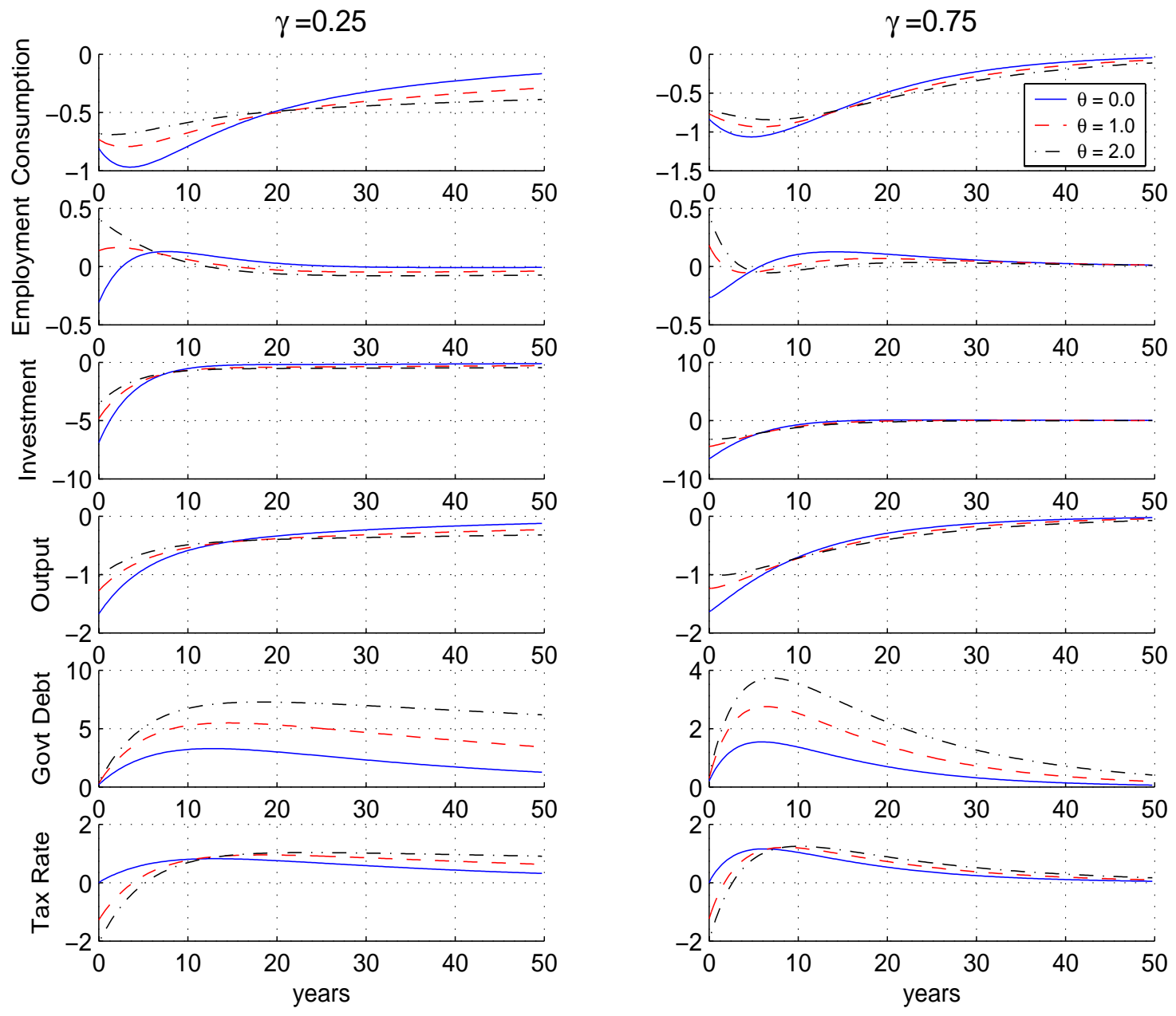

Figure 8: Impulse responses to a $1 \%$ negative technology shock under monopolistic competition, for low $(\gamma=0.25)$ and high $(\gamma=0.75)$ feedback on government debt and varying degrees of the countercyclical element of taxes: $\theta=0.0$ (solid lines), $\theta=1.0$ (dash lines), and $\theta=2.0$ (dash-dot lines). 

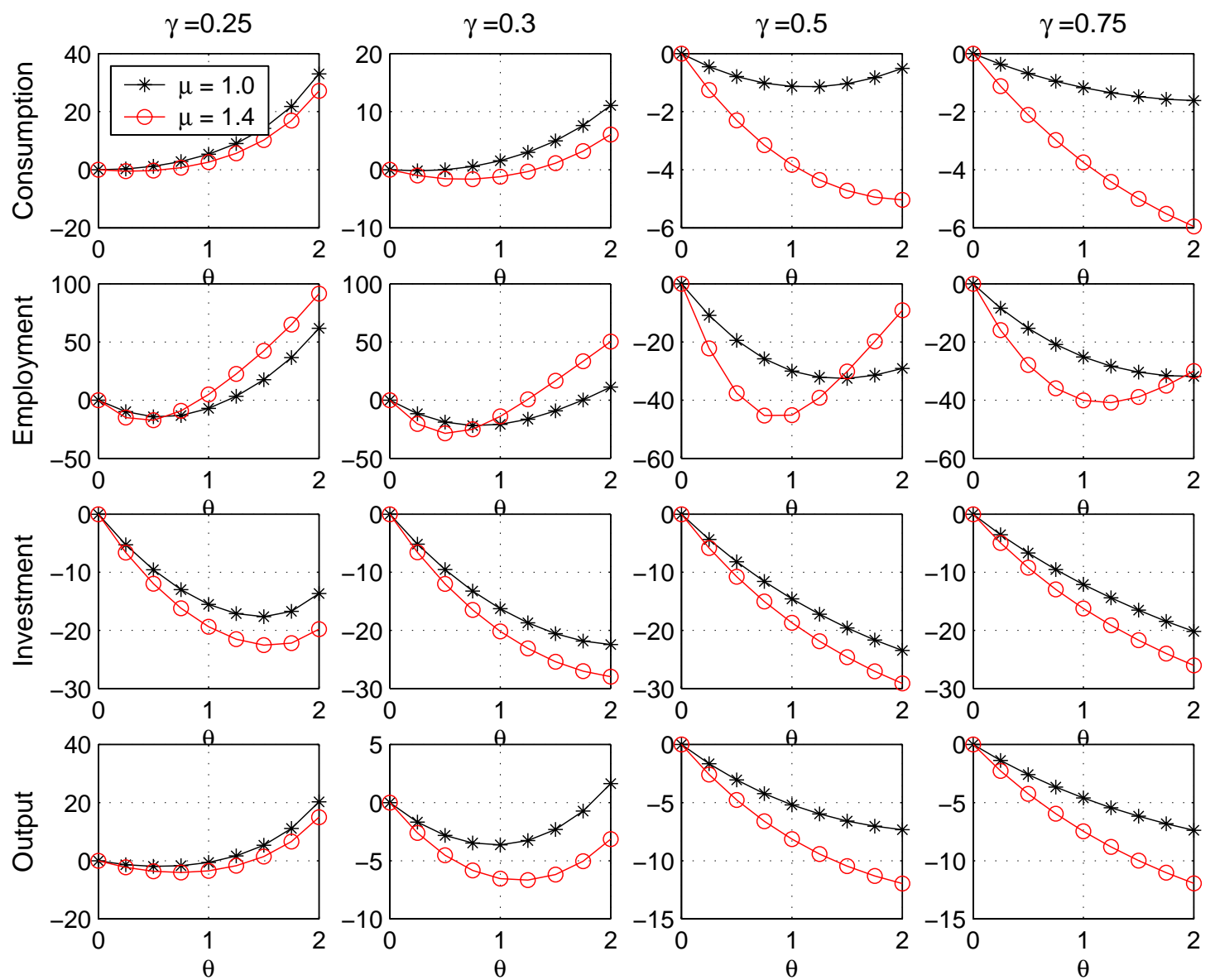

Figure 9: Percent changes in aggregate volatility as taxes become more countercyclical $(\theta>0)$ relative to acyclical taxes $(\theta=0)$ for different values of the fiscal feedback on debt, $\gamma$ : perfect competition (stars) and monopolistic competition (circles). Volatility is measured as the standard deviation of fluctuations around the long-run average. 